\title{
Quality Assurance of Vocational Education Trade/Entrepreneurship Subjects in Public Secondary Schools in Amuwo Odofin Local Government Area in Lagos State, Nigeria
}

\author{
Dr. Bolupe A. Awe ${ }^{1 *} \quad$ Dr. J.D.A. Utoware ${ }^{2}$ \\ ${ }^{1,2}$ Department of Educational Management and Business Studies \\ Faculty of Education, Federal University, Oye-Ekiti \\ *E-mail of the corresponding author: abayomi.awe@fuoye.edu.ng
}

\begin{abstract}
The study investigated quality assurance of Vocational Education trade subjects in public secondary schools in Amuwo-Odofin Local Government Area. Variables of quality assurance examined were the availability of physical facilities for teaching of vocational education trade subjects, the quality of these physical facilities as well as the as their adequacy. In addition, the quality of teaching personnel for vocational subjects as well as constraints to effective teaching of vocational education trade subjects in these public secondary schools in Amuwo-Odofin Local Government Area were also examined. Five research questions were raised for the study. The study adopted descriptive research survey. The sample of the study comprised of 147 respondents comprising of secondary school teachers in Amuwo-Odofin Local Government Area. A structured questionnaire was used to collect data from the subjects. The reliability coefficient of the instrument was 0.80 and the data collected were analyzed using frequency counts and percentages while histogram was used for illustration. The result of the study indicated that physical facilities were grossly inadequate and not readily available with low quality. The study also revealed that inadequate funding and shortage of subject specialists were major constraints to effective teaching of vocational subjects. Based on the findings of the study, recommendations were made.
\end{abstract}

Keywords: Quality Assurance, Physical Facilities, Vocational, Trade Subjects, Secondary School

DOI: $10.7176 / \mathrm{JEP} / 12-2-13$

Publication date: January $31^{\text {st }} 2021$

\section{Introduction}

Quality assurance is an essential tool required for efficient delivery of vocational education trade/entrepreneurship subjects at secondary school level in order to achieve manpower development and skill acquisition in our societies. Quality assurance is a proactive measure of ensuring quality and aims at preventing problems to ensure that the products of the system conform to the expected standards. It is a continuous process by which an institution can guarantee that standard and quality of its educational provision are being maintained and improved upon. Igborgbor (2012) maintained that quality assurance connotes all the measures taken to ensure that the educational system is better able to meet the needs of each society. Oladipo, Adeosun and Oni in Onyesom and Ashibogwu (2013) saw quality assurance as the relevance and appropriateness of the education programme to the needs of the community for which it is provided. They further asserted that it is the arrangement made or the mechanism put in place to maintain the degree of excellence of an educational products or services. Onyesom and Ashibogwu saw quality assurance as the entire process of ensuring maximum effectiveness and efficiency of educational programmes and services in relation to their context, mission and stated objectives.

The importance of vocational education in secondary schools has long been recognised as a bridge between education and employment and for providing a better match for the aptitudes and interests of pupils (Audu, Yusri, Muhammad \& Ali, 2013). Vocational education involves the application of specialized learning techniques in the realization of both educational and societal objectives, the main objectives revolve around the socio-economic, industrial and technological objective that will be evident in improved standard of living for citizens as well as in economic stability, industrial harmony and technological advancement (Ulinfun in Idialu, 2013). Vocational education therefore, equips an individual for economic independence, self - actualization and also being productive in various fields of learning. Vocational education emphasizes skill acquisition.

However, Singh, Grover, Padmanabham and Chaudhary (2015) saw vocational education as the totality of experiences through which one learns about and prepares to engage in work as a part of one's way of living. The authors explained further that vocational education encompasses all formal as well as informal instruction for students at the secondary or postsecondary level, and the working or displaced personnel; and prepares them by imparting and acquainting with the necessary skills, understandings, attitudes and abilities for entry into and advancement in a particular occupation or a cluster of related occupations. 
The unique nature of vocational education makes it different from other forms of education. Vocational education is capital-intensive due to its special requirement for workshop, tools and equipment. Fasae (2006) observed that with the high cost of education particularly science and technological education, where teaching involves the use of specialised laboratories, workshop machines, tools, equipment, materials and technically skilled teachers; not only are these things not locally and sufficiently available, but they are also very costly to purchase abroad and maintain for regular use in teaching. This view is buttressed by Yakubu (2002) in his observation that vocational education trade subjects require more instruction and practical time than general education subjects. Vocational education trade subjects need to be allotted sufficient time to satisfy their practical goals. Methods of assessment require the training of assessors who can assess students' competence in classrooms. All these make vocational education more expensive than other type of education.

Quality assurance in vocational education is a concept that is concerned with high performance involving activities such as teaching, learning, infrastructures, students' behaviour and the entire academic process. Quality vocational education refers to input and output of the programme, the expressions of standard by which certain goals can be achieved (Osahon, 2013). The concept of quality assurance and its implication for vocational education trade subjects cannot be over emphasised as the performance indicators of vocational education still requires serious attention in the secondary schools. The introduction of vocational education trade subjects at secondary school level as the basis for technological development and reduction in the rate of unemployment has its glaring challenges. All these challenges could constrain vocational education as stipulated in the National Policy on Education (FRN, 2013).

For instance, Ilusanya (2005) asserts that the general under-funding of education has affected vocational education and this is reflected in the dearth of facilities, personnel and material resources. Onwusonye (2005) posited that insufficient funding, lack of facilities and inadequate number of qualified instructors is factors inhibiting the implementation of vocational education programmes in Nigeria. Another major constraint is that of overcrowding. For effective participation of students in practical work, the recommended teacher-pupils ratio is 1:20 (FRN, 2013) However, it is not uncommon to find a situation whereby the teacher-pupil ratio is 1:100 in some public secondary schools. This makes practical impossible and lecture method an attractive mode of instruction for trade subjects.

Secondary school education is that form of education received after primary school education. It is the education received after primary education and before the tertiary stage. Federal Republic of Nigeria (FRN, 2013) stated the broad goals of secondary school education to be the preparedness of the individual for useful living within the society and higher education. The student at such period is expected to be in school for six years categorized into Junior Secondary (now upper basic education) and senior secondary. The first three years at the junior secondary level and the second part at the senior secondary level. At the end of the first three years, a student is awarded the Basic Education Certificate after passing the necessary examination(s). At the senior secondary level, students offered different subjects as classified under different areas such as science studies, technology studies, humanities, business studies and compulsory cross-cutting subjects (FRN, 2013). Students who complete junior secondary school shall be streamed into the senior secondary school; the technical college; an out-of-school vocational training center; or an apprenticeship scheme based on the result of tests to determine ability, aptitude and vocational interest which will make students offer six core subjects, a maximum of two elective subjects from vocational electives and two from non-vocational electives should register the maximum of nine subjects at the Senior Secondary Examination (Okoye \& Ogunleye, 2015).

At the first three years of secondary school education which is now the completion of Basic Education, a child is free to move to senior secondary school or technical college. Technical colleges are meant to provide trained manpower in the applied sciences, technology and business particularly at craft, advanced craft and technical levels; provide the technical knowledge and vocational skills necessary for agricultural, commercial and economic development; give training and impart the necessary skills to individual who shall be self-reliant economically. At present, the country runs 9-3-4 system of education after the failed in 6-3-3-4 system in achieving the goals and objectives of vocational education (Ementa, 2013), the nine-year basic educational programme captures students within the ages of 0-15 years is free, universal and compulsory for all children (FRN, 2013). Nine-year basic education comprises of 6years in primary education and 3 years of junior secondary education at the end of which students can proceed to senior secondary school or technical college which is not free, universal and compulsory as basic education. The last 4 years is meant for tertiary which is also optional.

Trade subjects otherwise known as entrepreneurial subjects were introduced into the new Senior Secondary School curriculum in Nigeria which was launched by the Federal Ministry of Education on March 14, 2011(Okoye \& 
Ogunleye, 2015). According to NERDC (2008), the senior secondary education curriculum consists of 34 trade/entrepreneurship subjects which are:

1. Auto Body repair and spray painting

2. Auto Electrical work

3. Auto Mechanical work

4. Auto Parts merchandising.

5. Air Conditioning Refrigerator

6. Welding and Fabrication Engineering Practice

7. Electrical installation and Maintenance Work

8. Radio, T.V and Electrical Work

9. Block laying, Brick Laying and Concrete Work

10. Painting and decoration

11. Plumbing and pipe fitting

12. Machine Woodworking

13. Carpentry and Joinery

14. Furniture Making

15. Upholstery

16. Catering and Craft Practice

17. Garment Making

18. Textile trade

19. Dyeing and bleaching

20. Printing Craft practice

21. Cosmetology

22. Leather Goods Manufacturing and Repair

23. Keyboarding

24. Shorthand

25. Data processing

26. Store keeping

27. Book keeping

28. GSM maintenance etc

29. Photography

30. Tourism

31. Mining

32. Animal Husbandry

33. Fisheries, and

34. Marketing and Salesmanship

Okoye and Ogunleye (2015) asserted that these trade/entrepreneurship subjects are vocational and technological and skill oriented subjects aimed at equipping the learners with manipulative skills which can enable them to be self-employed and self-reliant, thus reducing the problem of unemployment in the country. These subjects are designed to be practical oriented with entrepreneurial components and require a lot of practice. The philosophy behind the introduction of these trade subjects is that, every senior secondary school graduate should have been well prepared for higher education as well as acquired relevant functional trade/entrepreneurship skills needed for poverty eradication, job creation and wealth generation.

In spite of all the inherent advantages in the introduction of vocational education trade subjects in the secondary schools, studies have shown that effective teaching and learning of these subjects could be constrained by grossly inadequate of physical and human resources that might detect the teaching and learning process (Okoye \& Ogunleye). It has been perceived and observed by the researchers that trade subjects that require more of practical than theory are taught as any others subjects in Lagos State public secondary schools with its attendant implications on the quality of vocational education at the secondary schools, thus, the desirable for this study.

\section{Statement of the Problem}

Vocational education at secondary school level is perceived as panacea to unemployment situation in Nigeria. This is premised on the capability of this type of education to equip students with saleable skills and entrepreneurial spirit. However, peculiarities of vocational education make it capital intensive due to its huge capital outlay in terms of physical facilities and human resources required for instructional delivery at secondary schools. 
Experience has indicated that where all variables of quality assurance are constrained in a vocational institution, quality of outputs from such institution is impaired.

Lagos State appears to recognize the strategic role of vocational education through the establishment of five technical colleges. Products with flair for vocational subjects at secondary school level are expected to serve as feeders to these technical colleges. Therefore, it is imperative that quality of vocational subjects at the secondary schools must be commensurate with standards expected at technical colleges. This could only be achieved through with appropriate quality assurance measures.

It has been observed that shortage of equipment and facilities poses serious problem in vocational education trade subjects' instructional delivery. Most secondary schools lack relevant equipment for training, lack workshop and its facilities have ill-equipped laboratories and outdated laboratories. To teach vocational education trade subjects, there must be adequate provision of facilities in terms of space, equipment, to ensure quality of education in vocational education. The training environment should be like the work environment. Teaching with real materials and real situation can help to encourage the students to learn and enhance quality.

The continuous shortage of vocational experts has been identified as a major factor affecting the development and quality of vocational education trade subjects in public secondary schools in Nigeria. This shortage of qualified personnel could translate to underutilization of equipment and machines in some schools due to lack of competent hands to manipulate them. Quality cannot be guaranteed when the quality and quantity of personnel are inadequate to meet the desired expectation. It is in the light of the foregoing that this study is conducted.

\section{Purpose of the Study}

The purpose of the study was to ascertain the quality of physical facilities and human resources for efficient and effective teaching of vocational education trade subjects in public secondary schools in Amuwo Odofin Local Government Area of Lagos State, Nigeria. Specifically, the study sought to:

1. Determine the availability of physical facilities for vocational education trade subjects in public secondary schools in Amuwo Odofin L.G.A. in Lagos State

2. Determine the adequacy of physical facilities for vocational education trade subjects in public secondary schools in Amuwo Odofin L.G.A.in Lagos State

3. Determine the quality of physical facilities for the teaching of vocational education trade subjects in public secondary schools in Amuwo Odofin L.G.A. in Lagos State

4. Determine the availability of qualified teaching personnel for vocational education trade subjects in public secondary schools in Amuwo Odofin L.G.A. in Lagos State

5. Ascertain the constraints to the teaching of vocational education trade subjects in public secondary schools in Amuwo Odofin L.G.A. in Lagos State

\section{Research Questions}

The following research questions guided the study.

1. What is the extent of availability of physical facilities for teaching vocational education trade subjects in public secondary schools in Amuwo Odofin L.G.A?

2. What is the adequacy of physical facilities for teaching vocational education trade subjects in public secondary schools in Amuwo Odofin L.G.A?

3. What is the functionality of physical facilities for teaching vocational education trade subjects in public secondary schools in Amuwo Odofin L.G.A?

4. Are there sufficient qualified teaching personnel for teaching vocational education trade subjects in public secondary schools in Amuwo Odofin L.G.A?

5. What are the constraints to teaching of vocational education trade subjects in public secondary schools in Amuwo Odofin L.G.A? 


\section{Method}

The study adopted descriptive survey design. According to Nworgu (2015), a survey research design is one in which a group of people or items is studied by collecting and analyzing data from only a few people or items considered to be representative of the entire group. This design, therefore, was considered appropriate for the study as it collected data on the opinions of trade/entrepreneurship subjects' teachers in public secondary schools in Lagos State. The study was carried out in public public secondary schools in Amuwo Odofin L.G.A. The population for the study comprised all 143 trade subjects' teachers in the 15 public senior secondary schools in the L.G.A. The entire population was used for the study because of its manageable size; hence, there was no need for sampling. The data for the study were collected using a structured questionnaire. The instrument was constructed using a two point rating scale of "Available and Not Available" for research question 1 and 4; "High quality and Low quality" for Research question 2; "Adequate and Inadequate" for research question 3, and "Agree and Disagree" for research question 5. The questionnaire was validated by three experts. The questionnaire has a reliability index of 0.80 which was established through a pilot test on 20 trade subjects in public senior secondary schools in Oshodi-Isolo L.G.A. The internal consistency was determined using Cronbach Alpha procedure. Copies of the questionnaire were administered and collected by the researchers with the help of 10 research assistants after proper briefing on the purpose of the study. A total of 150 copies of questionnaire were distributed to the respondents. However, a total of 137 (91\%) were retrieved and found usable. Data collected were analyzed using frequency counts and percentage, while histograms were used for illustration.

\section{Results}

Research Question 1

What is the extent of availability of physical facilities for teaching vocational education trade subjects in public secondary schools in Amuwo Odofin L.G.A?

In analysing Research Question 1, scores on availability of physical facilities for vocational education subjects were used. The frequency scores were used to calculate the percentages for each item and presented in Table 1 . Table 1: Availability of Physical Facilities for Teaching Vocational Education Trade Subjects

\begin{tabular}{|l|l|l|l|l|l|}
\hline S/N & $\begin{array}{l}\text { Facilities for teaching vocational education } \\
\text { trade subjects }\end{array}$ & \multicolumn{2}{l}{ Available } & \multicolumn{2}{l|}{ Not Available } \\
\hline & Item & Freq & $\%$ & Freq & $\%$ \\
\hline 1 & Introductory Technology Workshop & 82 & 60 & 55 & 40 \\
\hline 2 & Technical drawing rooms & 38 & 28 & 99 & 72 \\
\hline 3 & Typing pools & 32 & 23 & 105 & 77 \\
\hline 4 & Home economic laboratory & 40 & 29 & 97 & 71 \\
\hline 5 & Creative art workshop & 24 & 17.5 & 113 & 82.5 \\
\hline 6 & Integrated science workshop & 25 & 18 & 112 & 82 \\
\hline 7 & Woodwork workshop & 19 & 14 & 118 & 86 \\
\hline 8 & Tailoring & 43 & 31 & 94 & 69 \\
\hline 9 & Auto mechanic workshop & 26 & 19 & 111 & 81 \\
\hline 10 & Bricklaying & 27 & 20 & 110 & 80 \\
\hline 11 & Shoe making & 27 & 20 & 110 & 80 \\
\hline
\end{tabular}

Table 1 shows physical facilities for teaching vocational education subjects in public secondary schools in Amuwo-Odofin Local Government Area. Table 1 revealed different scores under various items of physical facilities. Sixty percent of the respondents indicated that introductory technology workshop was available while most of the other physical facilities were not available as most of responses tended towards negative affirmation. In overall, the result shows below average performance in the various items on physical facilities for teaching of vocational education trade subjects. Only one out of the eleven items on physical facilities was available. This shows that in general, physical facilities for teaching vocational education trade subjects in these public secondary schools are not available.

Figure 1 reveals the extent of availability of physical facilities for teaching vocational education under the various items. Figure 1 shows that overall physical facilities were not available and disparities were observed under the different items. 


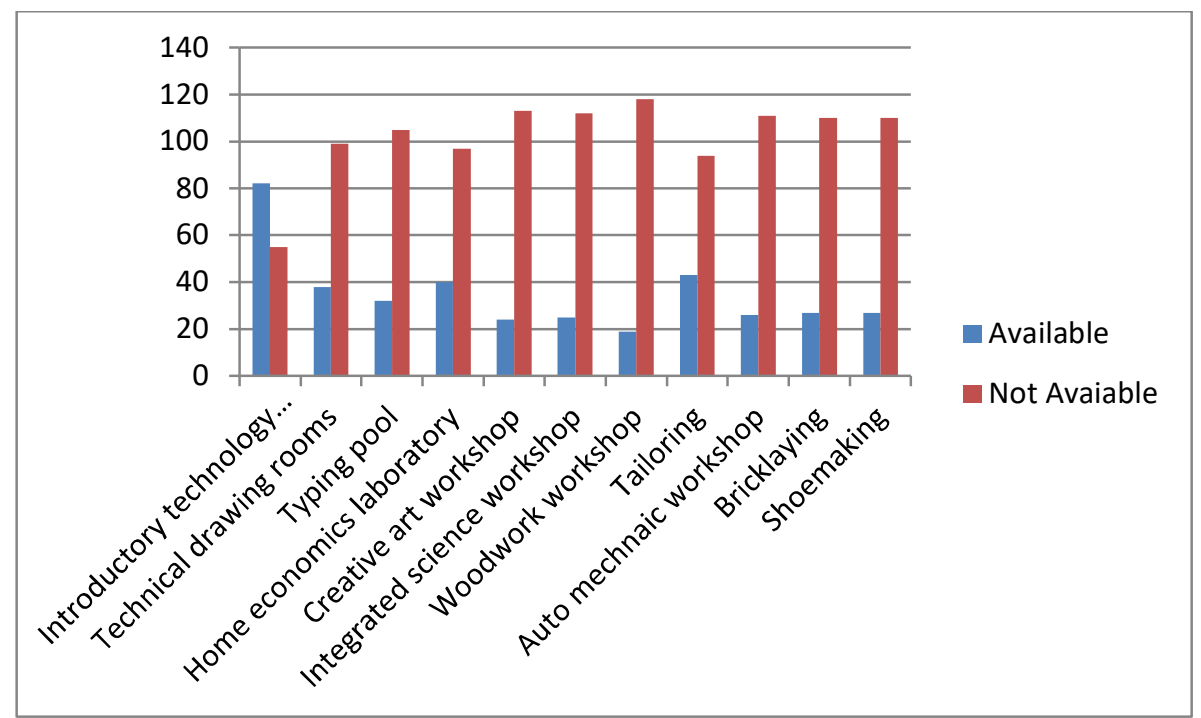

Figure 1: Availability of physical facilities for teaching vocational education trade subjects

Research Question 2

What is the adequacy of physical facilities for teaching vocational education trade subjects in public secondary schools in Amuwo Odofin L.G.A?

In analysing Research Question 2, scores on the adequacy of physical facilities for vocational education trade subjects were used. The frequency scores were used to calculate the percentages for each item and were presented in Table 2.

Table 2: Adequacy of Physical Facilities for Teaching Vocational Education Trade Subjects

\begin{tabular}{|l|l|l|l|l|l|}
\hline S/No & $\begin{array}{l}\text { Facilities for teaching vocational } \\
\text { education trade subjects }\end{array}$ & \multicolumn{2}{l}{ Adequate } & \multicolumn{2}{l}{ Inadequate } \\
\hline & Item & Freq & $\%$ & Freq & $\%$ \\
\hline 1 & Introductory Technology Workshop & 45 & 33 & 92 & 67 \\
\hline 2 & Technical drawing rooms & 28 & 20 & 109 & 80 \\
\hline 3 & Typing pools & 31 & 23 & 106 & 77 \\
\hline 4 & Home economic laboratory & 27 & 20 & 110 & 80 \\
\hline 5 & Creative art workshop & 24 & 17.5 & 113 & 82.5 \\
\hline 6 & Integrated science workshop & 33 & 24 & 104 & 76 \\
\hline 7 & Woodwork workshop & 34 & 25 & 103 & 75 \\
\hline 8 & Tailoring & 24 & 17.5 & 113 & 82.5 \\
\hline 9 & Auto mechanic workshop & 38 & 28 & 99 & 72 \\
\hline 10 & Bricklaying & 29 & 21 & 108 & 79 \\
\hline 11 & Shoe making & 26 & 19.0 & 111 & 81.0 \\
\hline
\end{tabular}

Table 2 shows the adequacy of physical facilities for vocational education trade subjects in these public secondary schools. Table 2 revealed that nearly all the physical facilities were inadequate. This is reflected in the trend where responses to availability of physical facilities are very high in the negative affirmation on all the items.

Figure 2 reveals the adequacy of physical facilities for teaching vocational education trade subjects under the various items. Figure 2 shows that overall adequacy of physical facilities was poor and disparities were observed under the different items. 




Figure 2: Adequacy of physical facilities

Research Question 3

What is the functionality of physical facilities for teaching vocational education trade subjects in public secondary schools in Amuwo Odofin L.G.A?

In analysing Research Question 3, scores on the functionality of physical facilities for vocational education trade subjects were used. The frequency scores were used to calculate the percentages for each item and were presented in Table 3

Table 3: Functionality of Physical Facilities for Teaching the Vocational Education Trade Subjects

\begin{tabular}{|l|l|l|l|l|l|}
\hline S/No & $\begin{array}{l}\text { Facilities for teaching vocational } \\
\text { education trade subjects }\end{array}$ & \multicolumn{2}{l|}{ Functional } & \multicolumn{2}{l|}{ Non-Functional } \\
\hline & Item & Freq & $\%$ & Freq & $\%$ \\
\hline 1 & Introductory Technology Workshop & 73 & 53 & 64 & 47 \\
\hline 2 & Technical drawing rooms & 36 & 26 & 101 & 74 \\
\hline 3 & Typing pools & 39 & 28.5 & 98 & 71.5 \\
\hline 4 & Home economic laboratory & 41 & 30 & 96 & 70 \\
\hline 5 & Creative art workshop & 27 & 20 & 110 & 80 \\
\hline 6. & Integrated science workshop & 32 & 23 & 105 & 77 \\
\hline 7 & Woodwork workshop & 49 & 36 & 88 & 64 \\
\hline 8 & Tailoring & 29 & 21 & 108 & 79 \\
\hline 9 & Auto mechanic workshop & 38 & 28 & 99 & 72 \\
\hline 10 & Bricklaying & 24 & 17.5 & 113 & 82.5 \\
\hline 11 & Shoe making & 31 & 23 & 106 & 77 \\
\hline
\end{tabular}

Table 3 shows the functionality of physical facilities for teaching vocational education trade subjects in public secondary schools in Amuwo-Odofin Local Government Area. Table 3 revealed different scores under various items of physical facilities. Fifty three percent of the respondents indicated that the functionality of introductory technology workshop was high while most of the other physical facilities for teaching of vocational education trade subjects were indicated to be of non-functional as most of responses tended towards negative affirmation. In overall, the result shows that the functionality of physical facilities for teaching of vocational education trade subjects was low. Only one out of the eleven items on physical facilities was rated to be of high quality. This shows that in general, physical facilities for teaching vocational education trade subjects in these public secondary schools were of low quality.

Figure 3 reveals the functionality of physical facilities for teaching vocational education trade subjects under the various items. Figure 3 shows that overall functionality of physical facilities was low and disparities were observed 
under the different items.

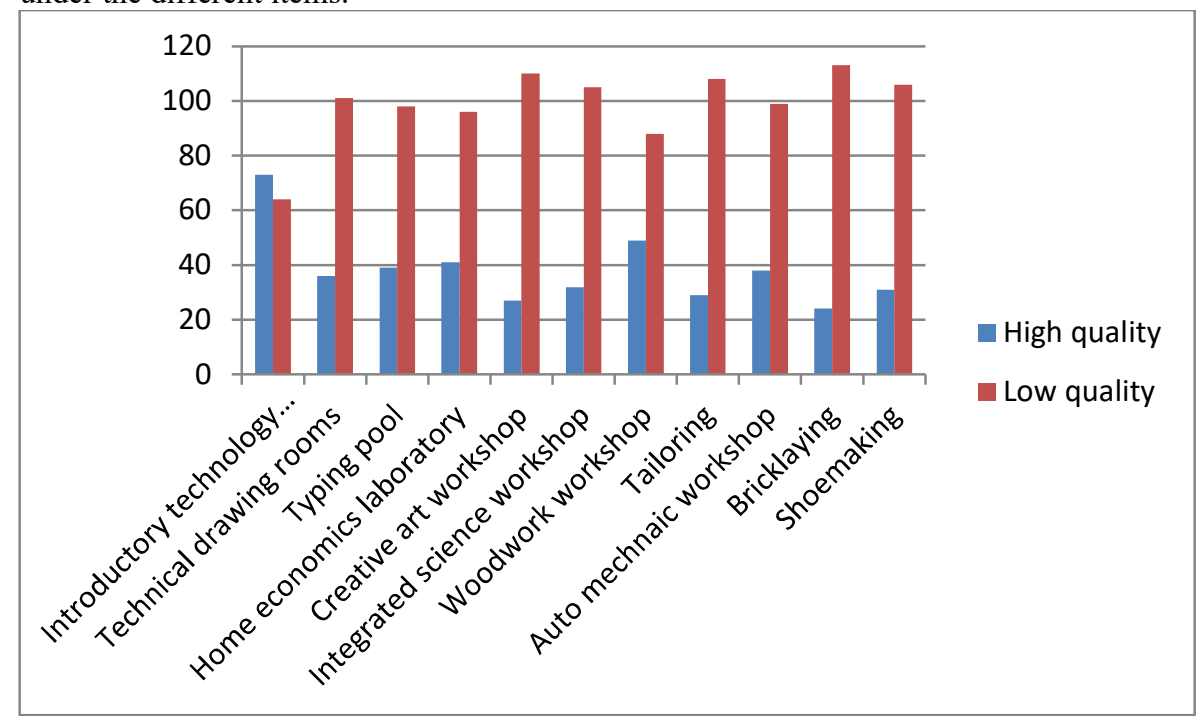

Figure 3: Functionality of physical facilities for vocational education trade subjects

Research Question 4:

Are there sufficient qualified teaching personnel for teaching vocational education trade subjects in public secondary schools in Amuwo Odofin L.G.A?

In analysing Research Question 4, scores on suffucient qualified teaching personnel for teaching vocational education trade subjects were used. The frequency scores were used to calculate the percentages for each item and were presented in Table 4.

Table 4: Sufficient Qualified Teaching Personnel for Teaching Vocational Education Trade Subjects

\begin{tabular}{|l|l|l|l|l|l|}
\hline S/No & Qualified Personnel to Use Materials & \multicolumn{2}{l|}{ Sufficient } & \multicolumn{2}{l|}{ Not Sufficient } \\
\hline & Item & Freq & $\%$ & Freq & $\%$ \\
\hline 1 & Introductory Technology Workshop & 71 & 52 & 66 & 48 \\
\hline 2 & Technical drawing rooms & 63 & 46 & 74 & 54 \\
\hline 3 & Typing pools & 58 & 42 & 79 & 58 \\
\hline 4 & Home economic laboratory & 58 & 41 & 81 & 59 \\
\hline 5 & Creative art workshop & 35 & 25.5 & 102 & 74.5 \\
\hline 6 & Integrated science workshop & 35 & 25.5 & 102 & 74.5 \\
\hline 7 & Woodwork workshop & 65 & 47 & 72 & 53 \\
\hline 8 & Tailoring & 27 & 20 & 110 & 80 \\
\hline 9 & Auto mechanic workshop & 55 & 40 & 82 & 60 \\
\hline 10 & Bricklaying & 39 & 28.5 & 98 & 71.5 \\
\hline 11 & Shoe making & 34 & 25 & 103 & 75 \\
\hline
\end{tabular}

Table 4 shows that there is shortage of qualified teaching personnel for teaching vocational education trade subjects in these public secondary schools. This appears evident in the trend where responses tend towards negative affirmation.

Figure 4 reveals the availability of qualified personnel for teaching vocational education trade subjects under the various items. Figure 4 shows that overall there was dearth of qualified vocational education teachers under the different items. 


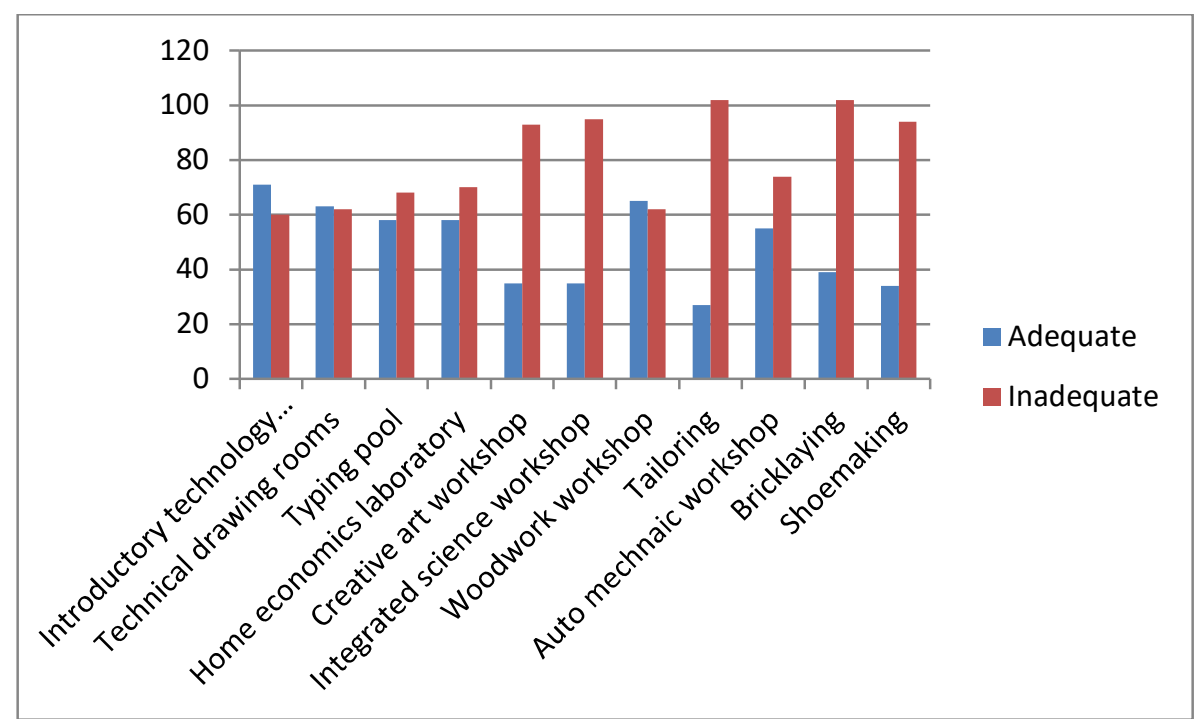

Figure 4: Sufficient qualified personnel for teaching vocational education trade subjects

Research Question 5

What are the constraints to teaching of vocational education subjects in public secondary schools in Amuwo Odofin L.G.A?

In analysing Research Question 5, scores on the constraints facing the teaching of vocational education trade subjects were used. The frequency scores were used to calculate the percentages for each item and were presented in Table 5.

Table 5: Constraints to Teaching of Vocational Education Trade Subjects

\begin{tabular}{|l|l|l|l|l|l|}
\hline S/N & $\begin{array}{l}\text { Constraints to Teaching of Vocational } \\
\text { Education Trade subjects }\end{array}$ & \multicolumn{2}{l|}{ Agree } & \multicolumn{2}{l|}{ Disagree } \\
\hline & Item & Freq & $\%$ & Freq & $\%$ \\
\hline 1. & Inadequate funding & 72 & 53 & 65 & 47 \\
\hline 2. & Lack of effective management & 78 & 57 & 59 & 43 \\
\hline 3. & Inadequate power supply & 87 & 63.5 & 50 & 36.5 \\
\hline 4. & No standby generator & 100 & 73 & 37 & 27 \\
\hline 5. & Negative attitude of the society & 105 & 77 & 32 & 23 \\
\hline 6. & Lack of subject specialists & 74 & 54 & 63 & 46.0 \\
\hline
\end{tabular}

Table 5 shows some of the constraints to instructional delivery of vocational education trade subjects in these public secondary schools. Table 5 revealed different scores under various items of constraints to instructional delivery of vocational education trade subjects in these public secondary schools. Fifty three percent of the respondents indicated funding as a constraint $59 \%$ agreed that resources were not adequately managed. Sixty three and half percent agreed on erratic supply of power while $73 \%$ admitted there was no standby generator. Seventy seven percent of the respondents agreed that negative attitude of the society towards vocational education trade subjects was a constraints while 54\% identified inadequate personnel for teaching vocational education trade subjects as constraint.

Overall, the result shows that enormous challenges are facing the teaching of vocational education trade subjects in these secondary schools. In general, responses to constraints were positive in all the items relating to challenges of teaching vocational education trade subjects in these public secondary schools.

Figure 5 reveals the constraints to the teaching of vocational education trade subjects in these secondary schools. Figure 5 shows the enormous challenges confronting teaching of vocational education trade subjects in these public secondary schools. 


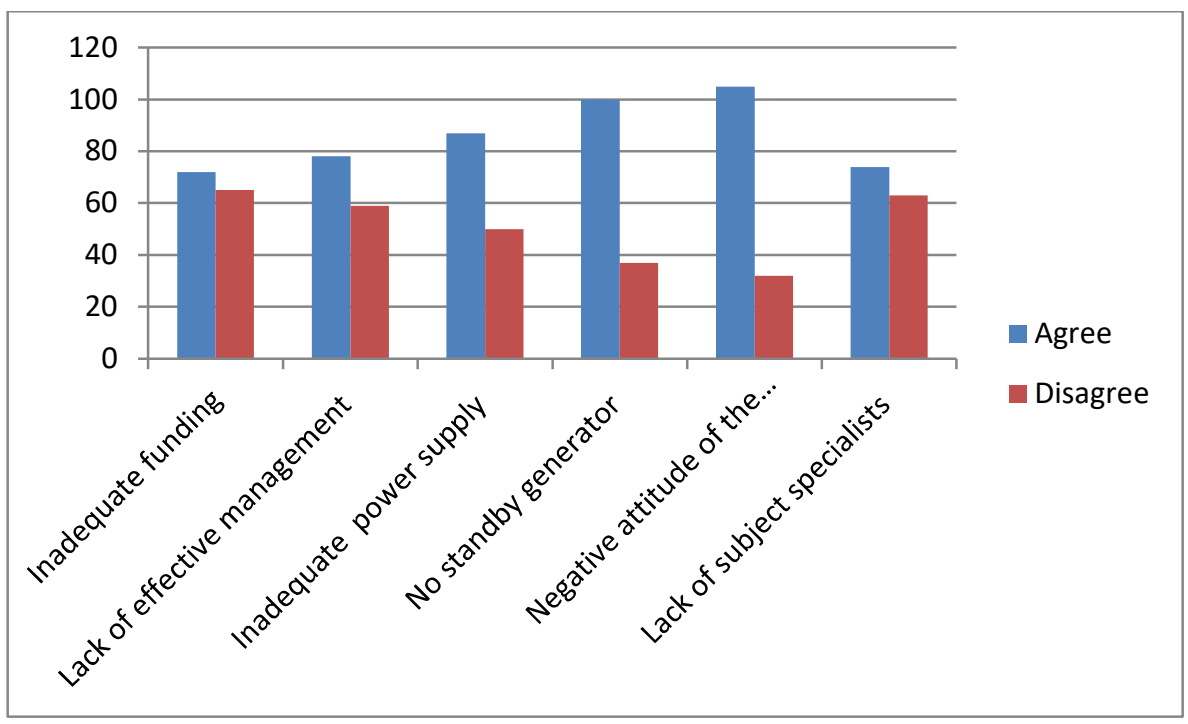

Figure 5: Constraints to teaching of vocational education Subjects

\section{Discussion}

The study revealed low availability of physical facilities for the teaching of vocational education trade subjects in public secondary schools in AmuwoOdofin Local Government Area. However, when physical facilities were classified into categories, physical facilities were adjudged as available only for introductory technology workshop while greater number of respondents indicated they were not available for the other physical facilities. This corroborates Okoye and Ogunleye (2015) whom asserted that in spite of all the inherent advantages in the introduction of vocational education trade subjects in the secondary schools, studies has showed that effective teaching and learning of these subjects could be constrained by grossly inadequate of physical and human resources that might detect the teaching and learning process. This has negative implication on instructional delivery of vocational education trade subjects in these public secondary schools.

The study also indicated that the functionality of physical facilities for vocational education trade subjects in these public secondary schools is very low. This is revealed in a situation where out of eleven items, most of the respondents agreed that only the functionality of introductory technology highly rated while all others were rated low. This does not augur well for the realization of the objectives of vocational education. It implies that functionality is positively skewed in favour of introductory technology. It then follows that students' interest in order disciplines is not given priority. In addition, the study also showed that physical facilities were grossly inadequate. The outcome of this study aligns with Ilusanya (2005) who identified lack of physical facilities as the bane of technical education.

In the area of teaching personnel for vocational education trade subjects, one of the findings of the study was chronic shortage of vocational teachers. When viewed against the crucial roles of teachers in teaching- learning process, it portends great danger to quality of vocational education trade subjects. This is because in teachinglearning process, the teacher factor is considered the most significant aspect. The study further revealed that except in introductory technology, technical drawing and typing, most of the teaching personnel had insufficient teaching experience. The outcome of this study reaffirms Anakobe (2002) and Aturuka (2006) in their observation that shortage of personnel was a threat to vocational education trade subjects.

The study revealed some major constraints to quality of vocational education trade subjects in these public secondary schools. For instance, lack of necessary tools for teaching vocational education trade subjects was one of such constraints. This has serious implication on the quality of output from these secondary schools. The tendency is that most of the students that are produced might not have relevant skills in the area of practical. This is because they are unable to utilize necessary tools that are meant to sharpen their manipulative skills.

In addition to the challenge of underfunding was the negative societal attitude towards vocational education trade subjects. For instance, when vocational subjects are perceived as subjects that are meant for drop outs, vocational education students are likely to suffer from low self-esteem that could affect their enthusiasm towards these subjects. This finding supports Okoye and Ogunleye (2015) who observed that biased attitude against technical education was a constraint to technical education. 
When the constraints to vocational education subjects were ranked in descending order of magnitude as indicated by the respondents, inadequate funding was top on the list. This is to be expected as finance is considered to be the most critical input in any human endeavour. This is because of the general perception that once money is available, all other inputs can be readily procured. Thus inadequate funding might be the root cause of other constraints associated with vocational education trade subjects in these public secondary schools.

\section{Conclusion}

In general all the indices of quality assurance for vocational education trade subjects in Amuwo-Odofin public secondary schools were lacking. For instance, there was inadequate provision of physical facilities while the available ones were adjudged as having low quality. There was dearth of specialists in most of the vocational education trade subjects coupled with inadequate experience. This has serious implication on the quality of instruction in vocational education trade subjects in Amuwo Odofin public secondary schools as well as the products from these institutions.

\section{Recommendations}

Based on the findings of this study, the following recommendations are made.

1. There is need for improvement in the quantity and quality of physical facilities for vocational education trade subjects.

2. Adequate provision must be made for the employment of vocational education trade subject specialists.

3. Adequate provision must be made for vocational education in budgetary allocation.

4. Government must lay emphasis on vocational education trade subjects in order to make it attractive to students and the society at large.

5. Government must enter into collaboration with private sector to provide opportunity for industrial attachment for acquisition of relevant skills by students.

\section{References}

Adegoke, K.A. (2002.). Standard in teacher preparation in Nigeria: Some highlights. Journal of Education for National development, 4(1 and 2); 1-6.

Amakobe, O.O. (2002): Focus of technical education in Nigeria: Aspiration, perception and realisation. In: S.O. Oriafo; P.O.Z. Nwankolo and G.C. Igborbgor (Eds). Refocusing education in Nigeria, Abraka: Faculty of Education, Delta State University, Nigeria.

Aturuka, J.O. (2006): Vocational education programmes in Nigeria: Issues and challenges. Journal of Research in Vocational and Technical Education. 2(1): 107-113.

Audu, R., Yusri, B.K., Muhammad, S.B.S. \& Ali, I. (2013). Quality assurance in technical vocational education for sustainable national development in the $21^{\text {st }}$ century. World Applied Sciences Journal, 28(3), 400-407.

Ementa, C.N, (2013).Curriculum implementation of entrepreneurial subjects at the senior secondary school: A case for entrepreneurship education at the senior secondary school in Nigeria. Unizik Orient Journal of Education 7 (1), 104-111.

Fasae, F.B.K. (2006): Training and Retraining Needs in Vocational Education for

National Development. Journal of Research in Vocational and Technical Education, 2(2) 59-64.

Federal Republic of Nigeria (2013). National policy on education ( $6^{\text {th }}$ Edition). Lagos: NERDC.

Idialu, E.E. (2013). Ensuring quality assurance in vocational education. Contemporary Issues in Education Research. 6(4), 431-438.

Igborgbor, G.C. (2012). Quality assurance for educational development in Africa. A key note address presented at the international conference of the institute of education, Delta State University, Abraka, Nigeria, June 12-15.

Ilusanya, G. (2005): The state of science, technical and vocational education in Nigeria: A manager's proposal for revitalisation. In A. Alani (Ed.), Managing the education system: Triumph-Providential Publishers.

NERDC (2008). The new senior secondary curriculum structure at a glance. Lagos: NERDC Press. 
Nworgu, B.G. (2015). Educational research: Basic issues and methodology (3rd edition). Nsukka: University Trust Publishers.

Okoye, K.R.E. \& Ogunleye, O.S. (2015). Trade subjects as compulsory subjects at the senior secondary schools in Nigeria: A subject for re-consideration. International Journal of Innovative Research and Development. 4(13); 40-44.

Onyesom, M. \& Ashibogwu, N.K. (2013). Towards quality assurance in business education in Nigeria: Constraints and control. Asian Journal of Business Management, 5(3), 306-312.

Osahon, M.E. (2013). Strategies for quality assurance in technical and vocational education programme in Nigeria. ABEN Books of Readings. 3(1), 177-180.

Salisu, R. A. (2001). The influence of school of physical resources on student academic performance. Unpublished M.Ed dissertation Department of Educational Administration, University of Lagos.

Singh, S.P., Grover, S., Padmanabhan, J. \& Chaudhary, S. (2015). Vocational education in higher secondary schools. Mediterranean Journal of Social Sciences. 6(5); 455-466.

Yakubu, N.A. (2002): Refocusing Vocational Technical Education in Nigeria. In: S.O. Oriafor; P.O.E. Nwankolo and G.C. Igborbgor (Eds) Refocusing Education in Nigeria.Abraka: Faculty of Education, Delta State University, Nigeria. 